School, Staffs., and A. E. Potter, Yorkshire College of Sciencc, to Entrance Scholarships at Christ's College ; H. Bury, third year, and F. W. Oliver, second year, to Foundation Scholarships at Trinity College.

S. F. Dufton, Grammar School, Bradford, has becn elected to an Oper Exhibition for Natural Science at Trinity College, and A. E. Mayeur, St. l'aul's, to an additional Exhibition.

\section{SCIENTIFIC SERIAT,S}

Journal of the Franklin Institute, 708, December, I884.-G. Forbes, dynamo-electric machinery; a full report of the lecture given by Prof. Forbes at the Philadelphia Exhibition.--R. I. Thurston, steam boilers as magazines of explosive energy. This paper contains lengthy numerical tables of the encrgy, expressed hoth in foot-pounds and in kilogrammetres, stored up in boilers containing given weight of water or steam at given pressures. According to these calculations a Lancashire two-flue boiler holding three tons of water working at $37 \mathrm{lbs}$. of steam pressure would, oy its explosion, liberate sufficient energy to blow itself nearly $2 \frac{1}{2}$ miles high, with an initial velocity of 900 leet per second.-E. J. Houston, glimpses of the International Electrical Exhibition, Nos. 2 and 3. These papers give accounts of Dolbear's electrostatic system of telcphony, and of Gray's telephonic inventions, with numerous illustrations.--L. d'Auria, the earth's ellipticity ; a reply to Prof. Chase.-Standard sizes of belt hoads and nuts, a reply by Mr. Coleman 'Sellers to Mr. simmonds.

\section{SOCIETIES AND ACADEMIES} LON ION

Royal Society, Nov. 27, 1884. - "Notes on the Microstopic Structure of some Rocks from the Andes of Ecuador, collected by E. Whymper. No. V. (conclusion). Altar, Illiniza, SinchoJagua, Cotocachi, Sara-urcu, \&c." By Prof. T. G. Bonney, D.Sc., F.R.S.

The microscopic structure of rocks from the first four of these mountains was described, the specimens being less numerous than in some of the former cases. Altar, Sincholagua, and Cotocachi furnished augite-andesites, mostly hyperstheniferous; Illiniza, micaceous and hornblendic augite-andesites. Sara-urcu was not a volcanic mountain, the specimens all being metamorphic rocks, varieties of gneiss and schists, similar to those which occur among the less ancient metamorphic rocks of the Alps and the Scotch Highlands; hence, probably, Archæan, but not the very oldest Archrean. A few miscellaneous specimens were also described, and the paper concluded with some general remarks and a summary of results.

January 15.- "On the Chemical Composition of the Cartilage occurring in certain Invertebrate Animals." By W. D. Halliburton, M.D., B.Sc. (Lond.), Sharpey Physiological Scholar, University College, London. Communicated by Prof. E. A. Schäfer, F.R.S. (from the Physiological Laboratory, University College, London).

At Prof. Lankester's suggestion I have submitted to chemical analysis the cartilages occurring in Sepia and in Limulus.

The basis of the cartilage is a chondrin-like body which gives the reactions of mucin and grelatima(indeed, chondrin, as it occurs in the ordinary hyaline cartilage of Verlebrates, is now regarded by many as a mechanical mixture of these (wo bodies). But in the cartilages of the two Invertebrates in question the gelatinous element is exceedingly small, and no gelatinisation occurs on the cooling of the hot watery extract.

In addition to this, however, the cartilage of both these animals differs from that of Vertebrates in containing a certain small percentage of chitin. In the case of Limulus $r$ or per cent., and of Sepia 1.22 per cent., of chitin, in the dry state is present.

I have also demonstrated that chitin cxists in the liver of the king crab, though whether in the connective tissue or in the liver cells themselves I cannot say. (The connective tissue element is very abundant in the liver of this animal, and it. seerns probable, looking at the part that chitin plays as a supporting structure in these animals, that it really forms in this instance a partial basis for the connective tissue.)

The way in which chitin was demonstrated to cxist was the same in all three cases, viz. :-

(I) After digesting with potash, a residue insoluble in boiling alkalics remains bchind.
(2) This residue, which, when washed and dried, is obtainable in a white amorphous condition, is insoluble in weak acids ; but in concentrated mineral acids it is soluble in the cold.

(3) On boiling the solution in sulphuric acid, a body which has the power of reducing cupric salts is formed.

(4) On boiling the solution in hydrochloric acid it turns brown, and on evaporating this solution to dryness a body crystallises out which has all the properties of hydrochlorate of glycosamine.

(I prepared some of this body from the chitin contained in the exoskelston of cockroaches, and also obtained from Prof. Lankester some crystals of the same body which Prof. Gamgee had kindly sent him.)

I was (thus) enabled to compare the crystalline bocty I hat obtained from the invertebrate cartilage with that of the pure hydrochlorate of glycosamine, and they were found to agree in the following points:-

(a) Crystalline form: rhombic prisms of the monoclinic system; measurement of the angles gave the same result in all cascs.

(b) Action of polarised light : nil.

(c) Solubilities : casily soluble in water, soluble with difficulty in alcohol.

These results are especially interesting as showing that chitin is not a body which is exclusively epiblastic in origin, but in these three instances at least occurs in mesoblastic structures.

Mathematical Society, January 8.- J. W. L. Glaisher, F.R.S., President, in the chair.--Messrs. F. R. Barrell, S. O. Koberts, and Prof. M. N. Dult, St. Stephen's College, Delhi, were elected members. The Rev. T. C. Simmons was admitted into the Society. - Prof. M. J. M. Hill read a paper on the differential equations of cylindrical and annular vortices. - The Rev. R. Harley, F.R.S., spoke on criticoids. - The following further communications were made:-Multiplication of symmetric functions, by Capt. Macmahon, R.A.-Note on symmetrical determinants, by A. Buchheim.--Results in elliptic functions, by the President (J. J. Walker, F.R.S., Vice-Presictent, in the chair).--Mr. Tucker read a second note by Prof. Gayley, F.R.S., on the binomial equation $x^{p}-1=0$ : quinquisectioin, and communicated a second paper, by $\mathrm{H}$. MacColl, on the simits of multiple integrals.

Victoria Institute, January $19-1$ paper on the historical evidences of the $\Lambda$ bramic migration was read by $\mathrm{Mr}$. W. Boscarven, in which he gave extracts from the new translations of some tablets which had been discovered by Mr. Rassam during his last visit to the East. These extracts contained a large number of names of persons and cities mentioned in the Bible record of the times to which they referred.

\section{EDINBURGH}

Royal Society, January 5.-L. Sang, L.L.D., Vice-President, in the chair.-Mr. Harvey Gibson submitted a paper on the anatomy of Patella vulgata.-Mr. W. W. J. Nicol read a paper on a theory of solution. Solution of a salt in a liquid results from the attraction of the molecules of the liquid for a molecule of the salt excecding the attraction of the molecules of salt for one another. Saturation ensues when these attractions are balanced. The theory explains variation of solubility with rise of temperature. Mr. Nicol brought forward experimental evidence in support of his views. - Mr. If. R. Mill, chemist to the Cranton Marine Station, read a paper on the salinity of the water of the Firth of Forth. Results were given, showing the variation of salinity along the Firth for high and low watcr.

\section{PARIS}

Academy of Sciences, Jannary 12.-M. Bouley, President, in the chair.- Thermo chemical experiments with phosphorous fluoride, a new gas recently discovered by M. Mnissan, by M. Berthelot.-Anatomical description of Ganidia Garnotii, Payrandeau, a species of Ganidia very ahundant on the coast of Algeria, by M. de Lacazc-Duthiers.-Report on M. Iuvini's two memoirs dealing with the formation of hailstones and the development of electricity during thunderstorms, by the Commissioners, MM. Becquerel and Faye-On the formation of toxic alkaloids in cholera patients, by M. A. Villiers. Experiments made on two victims of cholera soon after death enabled the author to determine the presence of an alkalnid clearly characterised by its alkaline and chemical reactions. It is found chiefly in the intestine, and also in small quantities 